\title{
Copper Oxide-Antimony Oxide Entrapped Alginate Hydrogel as Efficient Catalyst for Selective Reduction of 2-Nitrophenol
}

\author{
Sher Bahadar Khan 1,2,*(D), Esraa M. Bakhsh ${ }^{1}$, Kalsoom Akhtar ${ }^{1}$, Tahseen Kamal 1,2, Yan Shen ${ }^{3}$ \\ and Abdullah M. Asiri 1,2
}

Citation: Khan, S.B.; Bakhsh, E.M.; Akhtar, K.; Kamal, T.; Shen, Y.; Asiri, A.M. Copper Oxide-Antimony Oxide Entrapped Alginate Hydrogel as Efficient Catalyst for Selective

Reduction of 2-Nitrophenol. Polymers 2022, 14, 458. https://doi.org/ $10.3390 /$ polym 14030458

Academic Editor: Dong Jin Yoo

Received: 28 November 2021

Accepted: 13 January 2022

Published: 24 January 2022

Publisher's Note: MDPI stays neutral with regard to jurisdictional claims in published maps and institutional affiliations.

Copyright: (C) 2022 by the authors. Licensee MDPI, Basel, Switzerland. This article is an open access article distributed under the terms and conditions of the Creative Commons Attribution (CC BY) license (https:// creativecommons.org/licenses/by/ $4.0 /)$.
1 Chemistry Department, Faculty of Science, King Abdulaziz University, P.O. Box 80203, Jeddah 21589, Saudi Arabia; ibakhsh@kau.edu.sa (E.M.B.); kaskhan@kau.edu.sa (K.A.); tkkhan@kau.edu.sa (T.K.); aasiri2@kau.edu.sa (A.M.A.)

2 Center of Excellence for Advanced Materials Research, King Abdulaziz University, P.O. Box 80203, Jeddah 21589, Saudi Arabia

3 Wuhan National Laboratory for Optoelectronics, Huazhong University of Science and Technology, Luoyu Road 1037, Wuhan 430074,China; ciac_sheny@hust.edu.cn

* Correspondence: sbkhan@kau.edu.sa

\begin{abstract}
Copper oxide-antimony oxide $\left(\mathrm{Cu}_{2} \mathrm{O}-\mathrm{Sb}_{2} \mathrm{O}_{3}\right)$ was prepared and entrapped inside $\mathrm{Na}$ alginate hydrogel (Alg@C $\mathrm{Cu}_{2} \mathrm{O}-\mathrm{Sb}_{2} \mathrm{O}_{3}$ ). The developed $\mathrm{Alg} @ \mathrm{Cu}_{2} \mathrm{O}-\mathrm{Sb}_{2} \mathrm{O}_{3}$ was used as catalytic reactor for the reduction of 4-nitrophenol (4-NP), 2-nitrophenol (2-NP), 2,6-dinitrophenol (2,6-DNP), methyl orange $(\mathrm{MO})$, congo red $(\mathrm{CR})$, acridine orange $(\mathrm{AO})$, methylene blue $(\mathrm{MB})$ and potassium ferricyanide $\left(\mathrm{K}_{3}\left[\mathrm{Fe}(\mathrm{CN})_{6}\right]\right)$. Alg@Cu $\mathrm{Cu}_{2} \mathrm{O}-\mathrm{Sb}_{2} \mathrm{O}_{3}$ was found to be selective and more efficient for the reduction of 2-NP among all the pollutants. Therefore, 2-NP was selected for a detailed study to optimize various parameters, e.g., the catalyst amount, reducing agent concentration, 2-NP concentration and recyclability. Alg@ $\mathrm{Cu}_{2} \mathrm{O}-\mathrm{Sb}_{2} \mathrm{O}_{3}$ was found to be very stable and easily recyclable for the reduction of 2-NP. The Alg@ $\mathrm{Cu}_{2} \mathrm{O}-\mathrm{Sb}_{2} \mathrm{O}_{3}$ nanocatalyst reduced 2-NP in $1.0 \mathrm{~min}$, having a rate constant of $3.8187 \mathrm{~min}^{-1}$.
\end{abstract}

Keywords: Na-alginate; hydrogel wrapped copper oxide-antimony oxide; nitrophenols; dyes; potassium ferricyanide; catalytic reduction; water treatment; environmental applications

\section{Introduction}

Environmental pollution achieved worrying levels due to the continuous release and disposal of numerous pollutants into the environment and wastewater. Many of these pollutants are dyes and nitrophenols and are unsustainable in nature, which is of particularly great concern due to environmental regulations. These pollutants have high toxicity, hazardous nature, carcinogenicity, mutagenic nature, low biodegradability, and the fact that they are harmful and dangerous to living organisms [1,2]. Currently, dyes as well as phenols are believed to be tenacious, lethal, and dangerous contaminants coming from industrial wastewater [3,4]. These pollutants exist in the wastes of agrochemical, pharmaceutical, textile, and chemical industries because several industries are accountable for throwing out various pollutants into the ecosystem through wastewater streams. Consequently, the processes related to the disposal of the above-mentioned pollutants have foremost limitations, having a very slow removal proficiency, a poor elimination rate as well as being very costly and complex, which limits its applications [5,6]. Fortunately, researchers have focused a lot on detecting significant pollutants for different water bodies, but less work has been done on the removal or conversion of toxic pollutants [1,2]. Therefore, the efficient reduction and fast degradation of these pollutants is a central concern, considering its environmental and health hazards. One way to manage these pollutants from wastewater is by performing their reduction so as to produce less toxic or useful compounds. 
Various techniques are utilized regarding the removal of lethal pollutants from contaminated water [7]. However, these processes are believed to not be very useful for the complete removal of dangerous pollutants, or they require a long time. Second, the high cost also reduces their importance. Thus, easy, uncomplicated, and cheap methods are required for managing polluted wastewater $[3,8]$. Catalytic reduction is considered an inexpensive and good technique as it is easy, fast, and proficient. Catalytic reduction involves a very low quantity of solvent, and the time required for removal is also very short [9-11]. In recent times, many efforts have been made to prepare new catalysts and enhance their catalytic performance and stability as well as their selectivity regarding water pollutants [12-14].

Nanomaterials have eccentric and numerous applications in relation to human health, which they confer significantly to medicine and the environment. Nanomaterials demonstrate a good ability as catalysts, which is hardly possible when considering conventional systems. Nanomaterials retain a distinct shape, small size, and remarkable surface activity [15-19]. Tin oxide possesses a good ability and many applications, but still, it requires reformation to enhance its catalytic properties [20-22]. When considering many techniques, doping is the one that is used to reveal excellent properties in various areas. Dopants works to increase the surface area and alter the structure, modifying the morphology, which leads to enhanced properties of nanomaterials [23,24].

Doped metal oxides are efficient catalysts, but their utilization in powder form has several drawbacks such as aggregation, regeneration of the catalyst, recyclability and leaching. Therefore, to solve these problems, a $\mathrm{Cu}_{2} \mathrm{O}-\mathrm{Sb}_{2} \mathrm{O}_{3}$ nanomaterial was wrapped inside Na-alginate hydrogel to prevent this agglomeration and to make the recycling of metal oxide nanocatalysts easy, which is the novelty of the current study. For the current study, $\mathrm{Cu}_{2} \mathrm{O}-\mathrm{Sb}_{2} \mathrm{O}_{3}$ nanomaterial was prepared and checked by FESEM, EDS, XRD and FTIR. Further $\mathrm{Cu}_{2} \mathrm{O}-\mathrm{Sb}_{2} \mathrm{O}_{3}$ was entrapped inside Na-alginate hydrogel. Alg@ $@ \mathrm{Cu}_{2} \mathrm{O}-\mathrm{Sb}_{2} \mathrm{O}_{3}$ was initially tested for $\mathrm{MO}, \mathrm{CR}, \mathrm{ArO}, \mathrm{MB}$ and $\mathrm{K}_{3}\left[\mathrm{Fe}(\mathrm{CN})_{6}\right], 4-\mathrm{NP}, 2-\mathrm{NP}$ and 2,6-DNP, and we explored the efficiency of the $\mathrm{Alg} @ \mathrm{Cu}_{2} \mathrm{O}-\mathrm{Sb}_{2} \mathrm{O}_{3}$ nanocatalyst for the reduction of these pollutants. The Alg@Cu $\mathrm{Cu}_{2} \mathrm{O}-\mathrm{Sb}_{2} \mathrm{O}_{3}$ nanocatalyst achieved the greatest selectivity toward 2-NP, which underwent a reduction in $1.0 \mathrm{~min}$, having a superior rate constant.

\section{Experimental Section}

\subsection{Chemicals and Reagents}

Sodium alginate $\left(\mathrm{NaC}_{6} \mathrm{H}_{7} \mathrm{O}_{6}\right)_{n}$, copper nitrate, antimony chloride, $\mathrm{K}_{3}\left[\mathrm{Fe}(\mathrm{CN})_{6}\right]$ and $\mathrm{NaBH}_{4}$ were obtained from Sigma Aldrich. 4-NP, 2-NP and 2,6-DNP were obtained from Fluka. MO, CR, ArO, and MB were obtained from Merck, Germany.

\subsection{Preparation of $\mathrm{Cu}_{2} \mathrm{O}-\mathrm{Sb}_{2} \mathrm{O}_{3}$ and $\mathrm{Alg} @ \mathrm{Cu} u_{2} \mathrm{O}-\mathrm{Sb}_{2} \mathrm{O}_{3}$}

$0.1 \mathrm{M}$ solutions of antimony chloride and copper nitrate were initially prepared and then mixed. The mixed aqueous solution was stirred continuously, and then $0.1 \mathrm{M} \mathrm{NH}_{4} \mathrm{OH}$ was added and the $\mathrm{pH}$ was increased to 10 . The mixed solution was heated at $150.0^{\circ} \mathrm{C}$ for $10 \mathrm{~h}$ in an oven using an autoclave. The product was then filtered. After filtration, the product was dried after washing it thoroughly and was calcined at $400.0^{\circ} \mathrm{C}$ for $5 \mathrm{~h}$. The preparation process of $\mathrm{Alg} @ \mathrm{Cu}_{2} \mathrm{O}-\mathrm{Sb}_{2} \mathrm{O}_{3}$ and its utilization has been shown in Scheme 1. $\mathrm{Alg} @ \mathrm{Cu}_{2} \mathrm{O}-\mathrm{Sb}_{2} \mathrm{O}_{3}$ composite hydrogel was readily prepared by dispersing 3,5 and $10 \mathrm{mg}$ of $\mathrm{Cu}_{2} \mathrm{O}-\mathrm{Sb}_{2} \mathrm{O}_{3}$ in $1 \mathrm{~mL}$ of Alg individually. After that, $\mathrm{HCl}$ solution was added to the mixed solution. Alg was turned into hydrogel by $\mathrm{H}^{+}$after adding $\mathrm{HCl}$ solution because of $\mathrm{H}^{+}$crosslinking Alg. Alg@ $\mathrm{Cu}_{2} \mathrm{O}-\mathrm{Sb}_{2} \mathrm{O}_{3}$ was finally removed and washed by utilizing distilled water for the purpose of removing the unreacted $\mathrm{H}^{+}$present on the top surface of the hydrogel. The samples were examined by a field emission scanning electron microscope (FESEM, INSTRUMENT JSM-7600F, Japan), energy dispersive X-ray spectrometry (EDS, Oxford instruments Inc system), powder X-ray diffraction (XRD, ARL X'tra Thermo Scientific diffractometer), and a Fourier Transform Infrared spectrometer. The catalytic reduction was examined by a UV-Vis spectrometer (Evolution 300 by Thermo Scientific). 


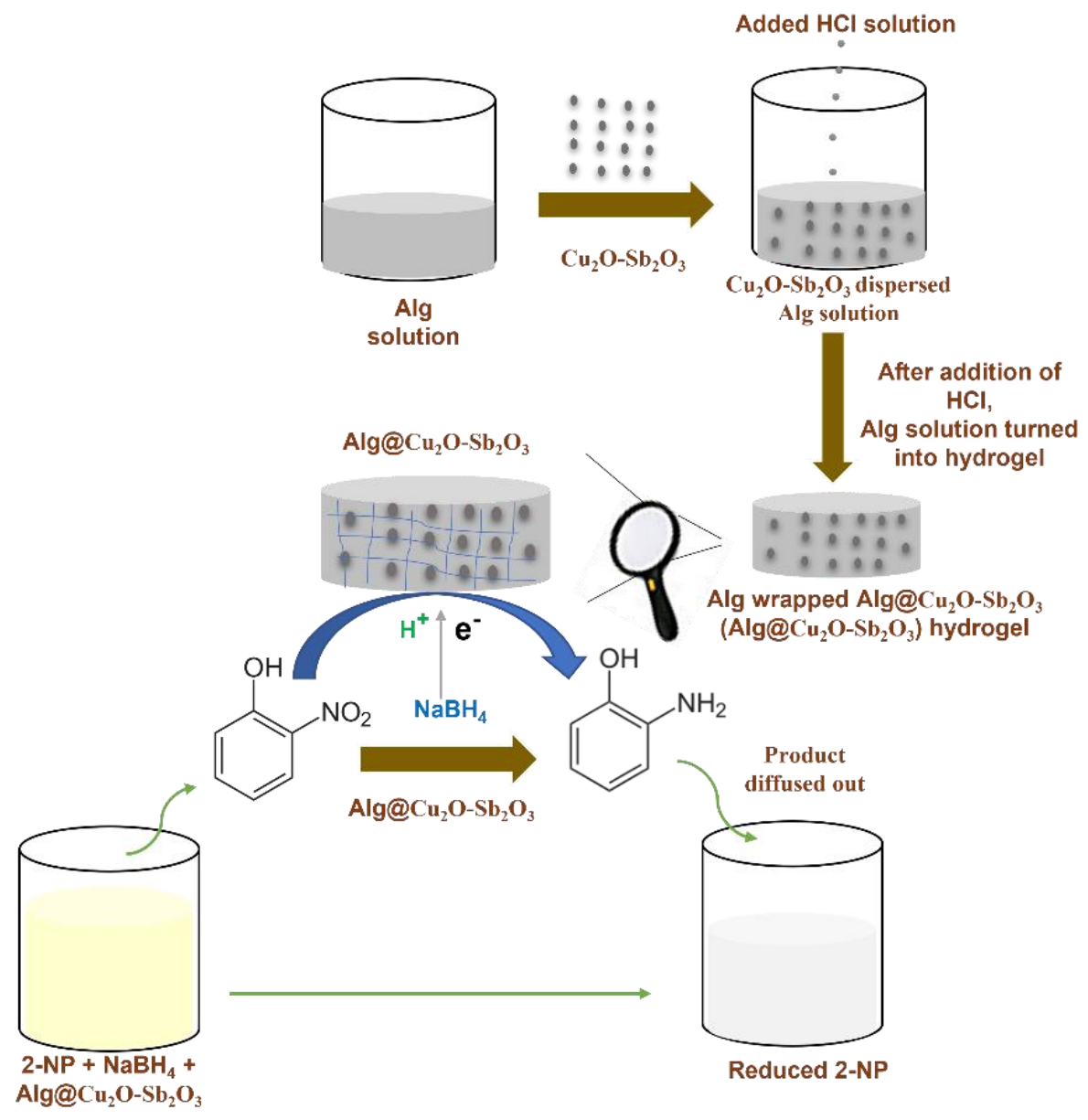

Scheme 1. Scheme of $\mathrm{Alg} @ \mathrm{Cu}_{2} \mathrm{O}-\mathrm{Sb}_{2} \mathrm{O}_{3}$ preparation and catalytic reduction of 2-NP.

\subsection{Catalytic Reduction}

At first, the $\mathrm{Alg} @ \mathrm{Cu}_{2} \mathrm{O}-\mathrm{Sb}_{2} \mathrm{O}_{3}$ hydrogel nanocatalyst was assessed with different dyes (CR (0.07 mM), MO (0.07 mM), ArO (0.07 mM), MB (0.07 mM)), $\mathrm{K}_{3}\left[\mathrm{Fe}(\mathrm{CN})_{6}\right](2.0 \mathrm{mM})$ and nitrophenols (4-NP $(0.13 \mathrm{mM}), 2-\mathrm{NP}(0.13 \mathrm{mM})$ and 2,6-DNP $(0.13 \mathrm{mM}))$. The catalytic reaction of the selected dyes, $\mathrm{K}_{3}\left[\mathrm{Fe}(\mathrm{CN})_{6}\right]$ and nitrophenols was performed by $\mathrm{Alg} @ \mathrm{Cu}_{2} \mathrm{O}$ $\mathrm{Sb}_{2} \mathrm{O}_{3}$ catalyst in the presence of $\mathrm{NaBH}_{4} .2 .5 \mathrm{~mL}$ of pollutant solution was poured in a cuvette, and its UV spectrum was checked. $0.5 \mathrm{~mL}$ of $\mathrm{NaBH}_{4}(0.1 \mathrm{M})$ was poured into it, followed by the addition of the Alg@ $\mathrm{Cu}_{2} \mathrm{O}-\mathrm{Sb}_{2} \mathrm{O}_{3}$ hydrogel nanocatalyst to the reaction system, and then the UV-vis spectrum was measured with an interval of $1.0 \mathrm{~min}$. Consequently, the catalytic reactions of $\mathrm{CR}, \mathrm{MO}, \mathrm{ArO}, \mathrm{MB}, \mathrm{K}_{3}\left[\mathrm{Fe}(\mathrm{CN})_{6}\right], 4-\mathrm{NP}, 2-\mathrm{NP}$ and 2,6-DNP were analyzed by measuring the absorbance spectra at $490 \mathrm{~nm}, 460 \mathrm{~nm}, 465 \mathrm{~nm}$, $658 \mathrm{~nm}, 415 \mathrm{~nm}, 400 \mathrm{~nm}, 413 \mathrm{~nm}$ and $428 \mathrm{~nm}$, respectively, and the percent reduction (\%R) was measured using Equation (1):

$$
\% R=\frac{C_{i}-C_{e}}{C_{i}} \times 100
$$

$C_{i}=$ initial and $C_{e}=$ final concentrations of pollutants.

\section{Results and Discussion}

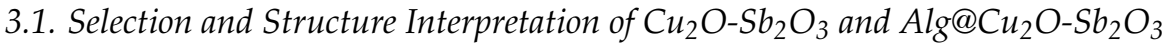

In search of an efficient, stable, and economical catalyst, a huge number of materials have been investigated. Among different materials, nanomaterials containing metal oxides play a very important part as a catalyst. As a catalyst, metal oxides have displayed good catalytic activities when considering different reactions. Thus, it was thought that 
doped metal oxides could be an excellent selection for the reduction reaction of pollutants. Consequently, $\mathrm{Cu}_{2} \mathrm{O}-\mathrm{Sb}_{2} \mathrm{O}_{3}$ and $\mathrm{Alg} @ \mathrm{Cu}_{2} \mathrm{O}-\mathrm{Sb}_{2} \mathrm{O}_{3}$ were prepared and tested in a reduction reaction of pollutants and discovered to be good catalysts because the Alg@C $\mathrm{u}_{2} \mathrm{O}-\mathrm{Sb}_{2} \mathrm{O}_{3}$ nanocatalyst showed a superb catalytic activity in relation to the catalytic reduction reaction of pollutants. However, it was more efficient for the reactions involving the 2-NP reduction, and it was, therefore, suggested that the $\mathrm{Alg} @ \mathrm{Cu}_{2} \mathrm{O}-\mathrm{Sb}_{2} \mathrm{O}_{3}$ nanocatalyst was a better choice for the reduction of 2-NP. Additionally, the composition, chemical structure, and morphology of $\mathrm{Cu}_{2} \mathrm{O}-\mathrm{Sb}_{2} \mathrm{O}_{3}$ was evaluated by FESEM, EDS, XRD and ATR-FTIR. The wrapping of $\mathrm{Cu}_{2} \mathrm{O}-\mathrm{Sb}_{2} \mathrm{O}_{3}$ inside $\mathrm{Alg}$ was confirmed by XRD and ATR-FTIR.

FESEM was utilized to check the morphology of $\mathrm{Cu}_{2} \mathrm{O}-\mathrm{Sb}_{2} \mathrm{O}_{3}$, and the FESEM images are displayed in Figure 1. The surface morphology of $\mathrm{Cu}_{2} \mathrm{O}-\mathrm{Sb}_{2} \mathrm{O}_{3}$ was explicated by comparing both the low and high magnification images. The $\mathrm{Cu}_{2} \mathrm{O}-\mathrm{Sb}_{2} \mathrm{O}_{3}$ images indicate that it is grown like sheets, which combine to construct a flower-shaped structure. Thus, $\mathrm{Cu}_{2} \mathrm{O}-\mathrm{Sb}_{2} \mathrm{O}_{3}$ is grown in nanosheets, for which the sheet diameter was observed to be $\sim 10 \mathrm{~nm}$. The images clearly show that $\mathrm{Cu}_{2} \mathrm{O}-\mathrm{Sb}_{2} \mathrm{O}_{3}$ has a flower-shaped morphology, where the flower is made of aggregated nanosheets, collectively giving a flower structure.
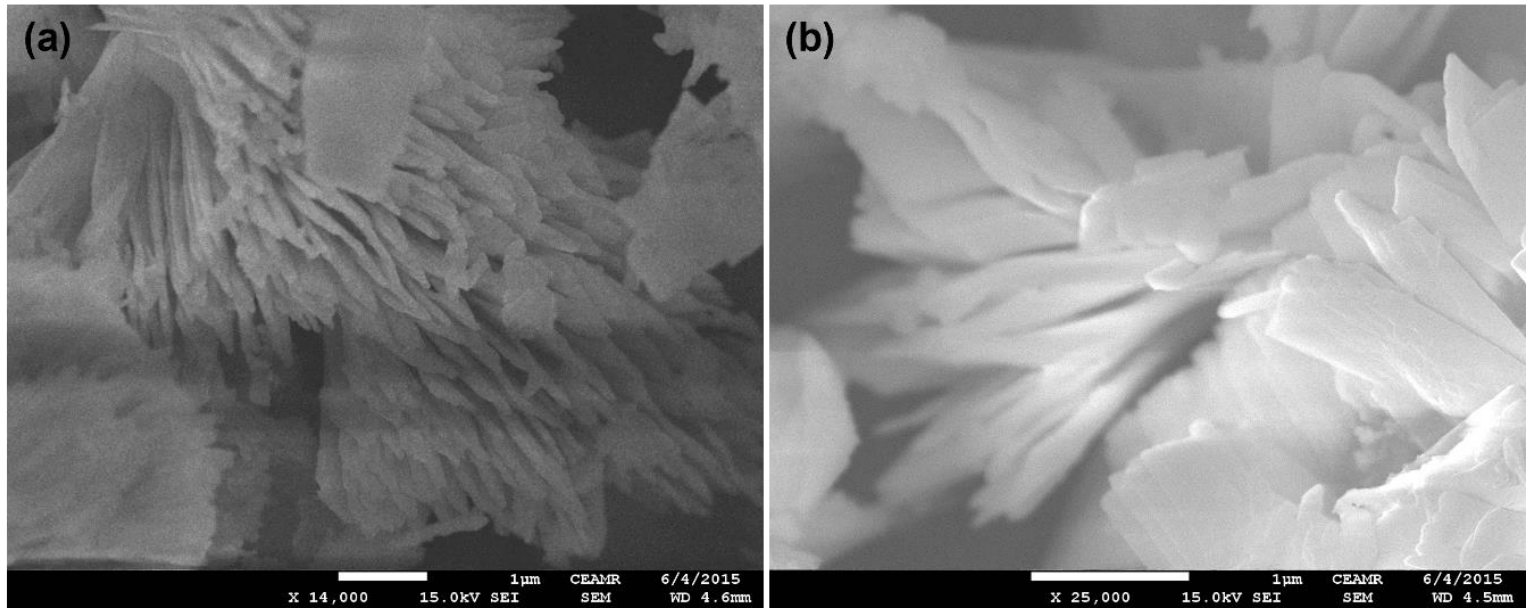

Figure 1. FESEM images of $\mathrm{Cu}_{2} \mathrm{O}_{-} \mathrm{Sb}_{2} \mathrm{O}_{3}$ at $(\mathbf{a}) \times 14,000$ and $(\mathbf{b}) \times 25,000$.

By using EDS, the compositional analysis of nanomaterial was examined, as shown in Figure 2. EDS displayed peaks related to antimony $(\mathrm{Sb})$, copper $(\mathrm{Cu})$ and oxygen $(\mathrm{O})$, showing the existence of the corresponding elements and suggesting their existence in the prepared nanomaterial. EDS revealed $71 \mathrm{wt} \%$ of $\mathrm{Sb}$ and $3 \mathrm{wt} \%$ of $\mathrm{Cu}$, indicating the growth of $\mathrm{Cu}_{2} \mathrm{O}$-doped $\mathrm{Sb}_{2} \mathrm{O}_{3}$. The lack of any extra peak in EDS suggested that the synthesized $\mathrm{Cu}_{2} \mathrm{O}-\mathrm{Sb}_{2} \mathrm{O}_{3}$ nanomaterial contained no impurity.

The XRD patterns of the prepared material clearly reveal peaks that correspond to the crystalline phase of $\mathrm{Cu}_{2} \mathrm{O}$ and $\mathrm{Sb}_{2} \mathrm{O}_{3}$ (Figure 3a). Hence, the XRD patterns imply that the prepared material is comprised of $\mathrm{Cu}_{2} \mathrm{O}$ and $\mathrm{Sb}_{2} \mathrm{O}_{3}$ phases. $\mathrm{Cu}_{2} \mathrm{O}-\mathrm{Sb}_{2} \mathrm{O}_{3}$ revealed diffraction peaks at $2 \theta=20.0,26.0,29.3,30.5,33.0,33.9,36.4,37.5,40.3,41.8,45.8,47.4,49.1$, $51.5,53.2,54.1,56.3,60.8,63.2,65.2$, and $68.3^{\circ}$. The diffraction lines at $2 \theta=30.5,36.4$ and $40.3^{\circ}$, which could be indexed to (110), (111), and (200), were assigned to $\mathrm{Cu}_{2} \mathrm{O}[25,26]$. All other peaks are well matched with the literature and could be assigned to the $\mathrm{Sb}_{2} \mathrm{O}_{3}$ phase. The intensities of the $\mathrm{Cu}_{2} \mathrm{O}$ peaks are low in the XRD pattern, which might be due to the low quantity of $\mathrm{Cu}_{2} \mathrm{O}$ phase present in $\mathrm{Cu}_{2} \mathrm{O}-\mathrm{Sb}_{2} \mathrm{O}_{3}$ when compared to the $\mathrm{Sb}_{2} \mathrm{O}_{3}$ phase. Therefore, the $\mathrm{Sb}_{2} \mathrm{O}_{3}$ diffraction peaks have significantly high intensities when compared to the $\mathrm{Cu}_{2} \mathrm{O}$ peaks. The XRD pattern suggests the possible formation of a two-phase material composed of $\mathrm{Cu}_{2} \mathrm{O}$ and $\mathrm{Sb}_{2} \mathrm{O}_{3}$ phases [24,27-29]. The Alg@ $\mathrm{Cu}_{2} \mathrm{O}-\mathrm{Sb}_{2} \mathrm{O}_{3}$ hydrogel XRD only demonstrated the pattern of the amorphous material. This peak can be attributed to the amorphous phase of $\mathrm{Alg}$. The $\mathrm{Alg} @ \mathrm{Cu}_{2} \mathrm{O}-\mathrm{Sb}_{2} \mathrm{O}_{3}$ pattern did not show any peak associated with the $\mathrm{Cu}_{2} \mathrm{O}-\mathrm{Sb}_{2} \mathrm{O}_{3}$ phase, the reason for this being either the presence of a lower quantity 
of $\mathrm{Cu}_{2} \mathrm{O}-\mathrm{Sb}_{2} \mathrm{O}_{3}$ in $\mathrm{Alg} @ \mathrm{Cu}_{2} \mathrm{O}-\mathrm{Sb}_{2} \mathrm{O}_{3}$ or $\mathrm{Cu}_{2} \mathrm{O}-\mathrm{Sb}_{2} \mathrm{O}_{3}$ being entirely wrapped up inside the $\mathrm{Alg}$ hydrogel. Consequently, the XRD pattern of $\mathrm{Alg} @ \mathrm{Cu}_{2} \mathrm{O}-\mathrm{Sb}_{2} \mathrm{O}_{3}$ only displayed peaks associated with the Alg phase. Thus, the XRD pattern suggested that $\mathrm{Cu}_{2} \mathrm{O}-\mathrm{Sb}_{2} \mathrm{O}_{3}$ was ensnared inside the Alg hydrogel.

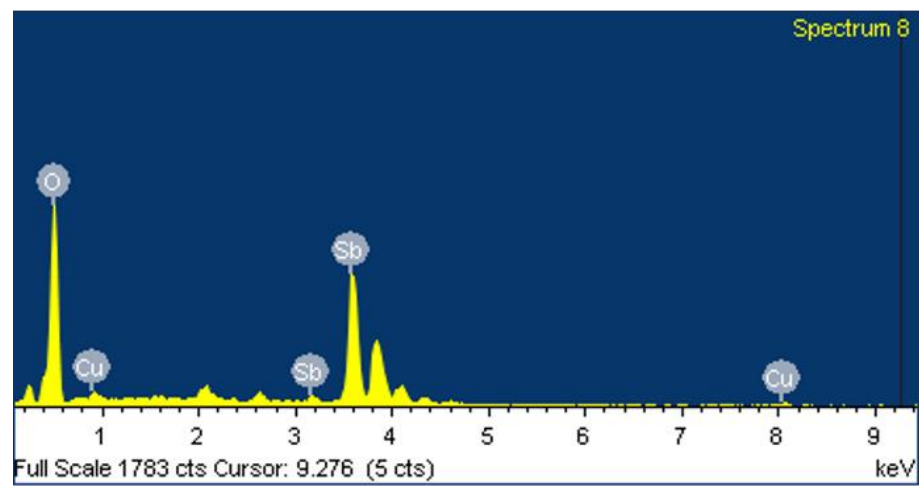

\begin{tabular}{|l|l|l|}
\hline Element & Weight\% & Atomic\% \\
\hline & & \\
\hline O K & 25.91 & 71.96 \\
\hline $\mathrm{Cu} \mathrm{L}$ & 3.01 & 2.11 \\
\hline $\mathrm{Sb} \mathrm{L}$ & 71.07 & 25.93 \\
\hline & & \\
\hline Totals & 100.00 & \\
\hline
\end{tabular}

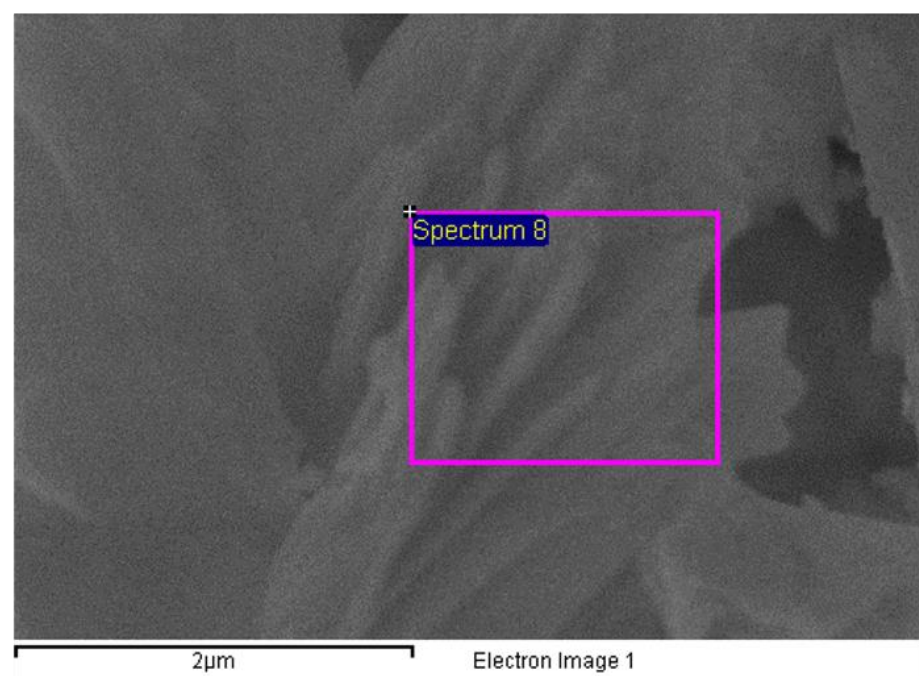

Figure 2. EDS of $\mathrm{Cu}_{2} \mathrm{O}-\mathrm{Sb}_{2} \mathrm{O}_{3}$.
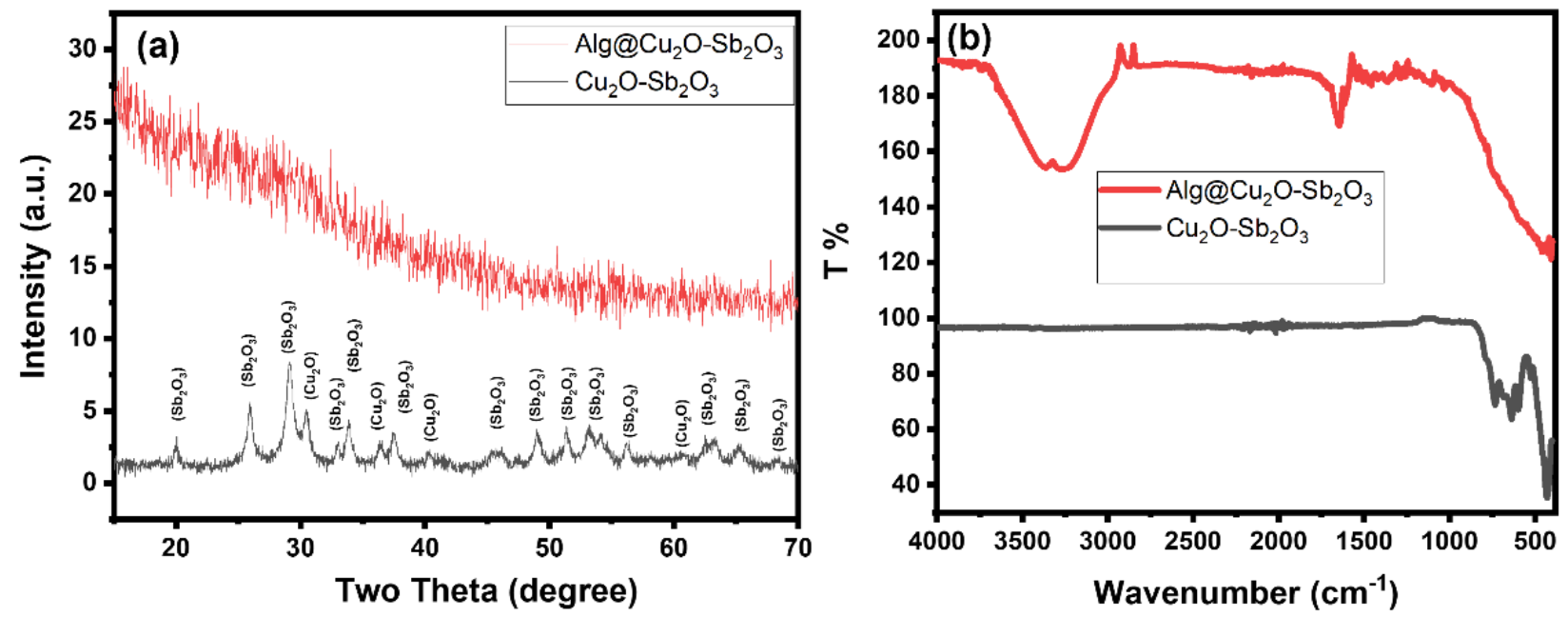

Figure 3. (a) XRD and (b) ATR-FTIR of $\mathrm{Cu}_{2} \mathrm{O}-\mathrm{Sb}_{2} \mathrm{O}_{3}$ and $\mathrm{Alg} @ \mathrm{Cu}_{2} \mathrm{O}-\mathrm{Sb}_{2} \mathrm{O}_{3}$ nanocatalysts.

The ATR-FTIR spectrum of $\mathrm{Cu}_{2} \mathrm{O}-\mathrm{Sb}_{2} \mathrm{O}_{3}$ indicated intense bands at 430, 590 and $631 \mathrm{~cm}^{-1}$ (Figure $3 \mathrm{~b}$ ). These bands indicate the growth of metal oxide ( $\mathrm{M}=\mathrm{O}$ stretching). The Alg@ $\mathrm{Cu}_{2} \mathrm{O}-\mathrm{Sb}_{2} \mathrm{O}_{3}$ nanocatalyst also displayed a high and intense broad band in the same region $\left(400 \sim 600 \mathrm{~cm}^{-1}\right)$, confirming the presence of $\mathrm{Cu}_{2} \mathrm{O}-\mathrm{Sb}_{2} \mathrm{O}_{3}$ [24,29]. The 
Alg@ $\mathrm{Cu}_{2} \mathrm{O}-\mathrm{Sb}_{2} \mathrm{O}_{3}$ nanocatalyst showed some additional bands at 1032, 1105, 1357, 1461, $1589,1643,1725,2878$, and 3200 3400, corresponding to Alg. The ATR-FTIR spectrum of $\mathrm{Alg} @ \mathrm{Cu}_{2} \mathrm{O}-\mathrm{Sb}_{2} \mathrm{O}_{3}$ indicated $\mathrm{C}-\mathrm{H}$ and $\mathrm{O}-\mathrm{H}$ bands at 2878 and $3268 \mathrm{~cm}^{-1}$. The symmetric and asymmetric stretching vibration bands at 1461, 1643 and $1725 \mathrm{~cm}^{-1}$ were attributed to carboxylate salt ion and $\mathrm{C}=\mathrm{O}$. The $\mathrm{C}-\mathrm{O}$ and $\mathrm{C}-\mathrm{C}-\mathrm{H}$ stretching vibration bands appeared at 1032, 1105 and $1357 \mathrm{~cm}^{-1}$. The ATR-FTIR spectra suggest that $\mathrm{Cu}_{2} \mathrm{O}-\mathrm{Sb}_{2} \mathrm{O}_{3}$ and the $\mathrm{Alg} @ \mathrm{Cu}_{2} \mathrm{O}-\mathrm{Sb}_{2} \mathrm{O}_{3}$ nanocatalyst were prepared without any impurities.

\subsection{Catalytic Activity of Alg@Cu $2 \mathrm{O}-\mathrm{Sb}_{2} \mathrm{O}_{3}$}

\subsubsection{Reduction of Organic Dyes}

Organic dyes are regarded as toxic pollutants, and consequently the prepared $\mathrm{Alg} @ \mathrm{Cu}_{2} \mathrm{O}$ $\mathrm{Sb}_{2} \mathrm{O}_{3}$ nanocatalyst was examined in order to evaluate the catalytic activity using $\mathrm{NaBH}_{4}$. The Alg@ $\mathrm{Cu}_{2} \mathrm{O}-\mathrm{Sb}_{2} \mathrm{O}_{3}$ nanocatalyst was applied for the reduction reaction of $\mathrm{CR}, \mathrm{MO}$, $\mathrm{ArO}$ and $\mathrm{MB}$. Figure $4 \mathrm{a}-\mathrm{d}$ exhibits the reduction of $\mathrm{CR}, \mathrm{MO}, \mathrm{ArO}$ and $\mathrm{MB}$ by $\mathrm{NaBH}_{4}$ and $\mathrm{Alg} @ \mathrm{Cu}_{2} \mathrm{O}-\mathrm{Sb}_{2} \mathrm{O}_{3}$. The results indicate that $\mathrm{Alg} @ \mathrm{Cu}_{2} \mathrm{O}-\mathrm{Sb}_{2} \mathrm{O}_{3}$ reduced $\mathrm{CR}, \mathrm{MO}, \mathrm{ArO}$ and $\mathrm{MB}$ within 3.0-6.0 min (Figure $4 \mathrm{a}-\mathrm{d}$ ). The current findings suggest the reduction of the azo $(-\mathrm{N}=\mathrm{N}-)$ group present in dye molecules through the transferring of electrons from $\mathrm{BH}_{4}{ }^{-}$to $\mathrm{Alg} @ \mathrm{Cu}_{2} \mathrm{O}-\mathrm{Sb}_{2} \mathrm{O}_{3}$ and, further, through shifting electrons toward the acceptor dye molecules [30,31]. The conversion (\%) was $97.14 \%, 97.86 \%, 50.59 \%$ and $97.38 \%$ for CR, MO, $\mathrm{ArO}$ and $\mathrm{MB}$, respectively, within $4.0 \mathrm{~min}, 3.0 \mathrm{~min}, 6.0 \mathrm{~min}$ and $4.0 \mathrm{~min}$ (Figure $4 \mathrm{e}$ ). The results suggested a high catalytic activity of $\mathrm{Alg} @ \mathrm{Cu}_{2} \mathrm{O}-\mathrm{Sb}_{2} \mathrm{O}_{3}$ toward the dyes reduction.

The pseudo-first-order equation was utilized to evaluate the reaction kinetics [32].

$$
r=\frac{\mathrm{d} c}{\mathrm{~d} t}=\ln \frac{c_{t}}{c_{0}}=-k_{a p p} t
$$

where $r$ stands for the reactant rate; $C$ is the reactant concentration; $t$ stands for the time of reaction; $k$ represents the reaction rate constant; $C_{t}$ stands for the dyes concentration at time $t$; and $C_{0}$ stands for the dyes concentration at time 0 .

The current study proves that the dyes reduction obeys pseudo-first-order kinetics. The rate constants were assessed as being $1.1929 \mathrm{~min}^{-1}, 1.4045 \mathrm{~min}^{-1}, 0.1131 \mathrm{~min}^{-1}$ and $0.9571 \mathrm{~min}^{-1}$ for $\mathrm{CR}, \mathrm{MO}, \mathrm{ArO}$ and $\mathrm{MB}$, respectively. These high-rate constants suggest that there is a quick diffusion of $\mathrm{BH}_{4}{ }^{-}$and dye molecules into $\mathrm{Alg} @ \mathrm{Cu}_{2} \mathrm{O}-\mathrm{Sb}_{2} \mathrm{O}_{3}$, where electron transfers take place from $\mathrm{NaBH}_{4}$ to dye molecules and quickly diffuse out the product.

\subsubsection{Reduction of $\mathrm{K}_{3}\left[\mathrm{Fe}(\mathrm{CN})_{6}\right]$}

$\mathrm{Alg} @ \mathrm{Cu}_{2} \mathrm{O}-\mathrm{Sb}_{2} \mathrm{O}_{3}$ was tested in the reduction reaction of $\mathrm{K}_{3}\left[\mathrm{Fe}(\mathrm{CN})_{6}\right]$ and $\mathrm{NaBH}_{4}$. At first, the $\mathrm{K}_{3}\left[\mathrm{Fe}(\mathrm{CN})_{6}\right]$ reduction was only performed by $\mathrm{NaBH}_{4}$ without $\mathrm{Alg} @ \mathrm{Cu}_{2} \mathrm{O}-\mathrm{Sb}_{2} \mathrm{O}_{3}$. The $\mathrm{K}_{3}\left[\mathrm{Fe}(\mathrm{CN})_{6}\right]$ reduction was very slow without $\mathrm{Alg} @ \mathrm{Cu}_{2} \mathrm{O}-\mathrm{Sb}_{2} \mathrm{O}_{3}$. Then, $10 \mathrm{mg}$ of Alg@ $\mathrm{Cu}_{2} \mathrm{O}-\mathrm{Sb}_{2} \mathrm{O}_{3}$ were placed into the mixture of $\mathrm{NaBH}_{4}$ and $\mathrm{K}_{3}\left[\mathrm{Fe}(\mathrm{CN})_{6}\right]$. Using visual observation, it was noticed that $\mathrm{K}_{3}\left[\mathrm{Fe}(\mathrm{CN})_{6}\right]$ bearing a yellow color faded immediately within few seconds and that within $3.0 \mathrm{~min}$ the absorbance band at $415 \mathrm{~nm}$ declined and disappeared, as demonstrated in Figure 5a. This indicates the reduction of $\mathrm{Fe}^{+3}$ to $\mathrm{Fe}^{+2}$ and hence the formation of $\left[\mathrm{Fe}(\mathrm{CN})_{6}\right]^{-4}$ [33]. The conversion (\%) was $97.98 \%$ for $\mathrm{K}_{3}\left[\mathrm{Fe}(\mathrm{CN})_{6}\right]$ within $3.0 \mathrm{~min}$ (Figure $5 \mathrm{~b}$ ), and thus the current study indicated that a good reduction was attained by $\mathrm{Alg} @ \mathrm{Cu}_{2} \mathrm{O}-\mathrm{Sb}_{2} \mathrm{O}_{3}$; additionally, the results suggested a high catalytic property of $\mathrm{Alg} @ \mathrm{Cu}_{2} \mathrm{O}-\mathrm{Sb}_{2} \mathrm{O}_{3}$ toward the $\mathrm{K}_{3}\left[\mathrm{Fe}(\mathrm{CN})_{6}\right]$ reduction. The kinetics of the $\mathrm{K}_{3}\left[\mathrm{Fe}(\mathrm{CN})_{6}\right]$ reduction were analyzed by applying Equation (2), and the rate constant was assessed to be $1.3180 \mathrm{~min}^{-1}$. 

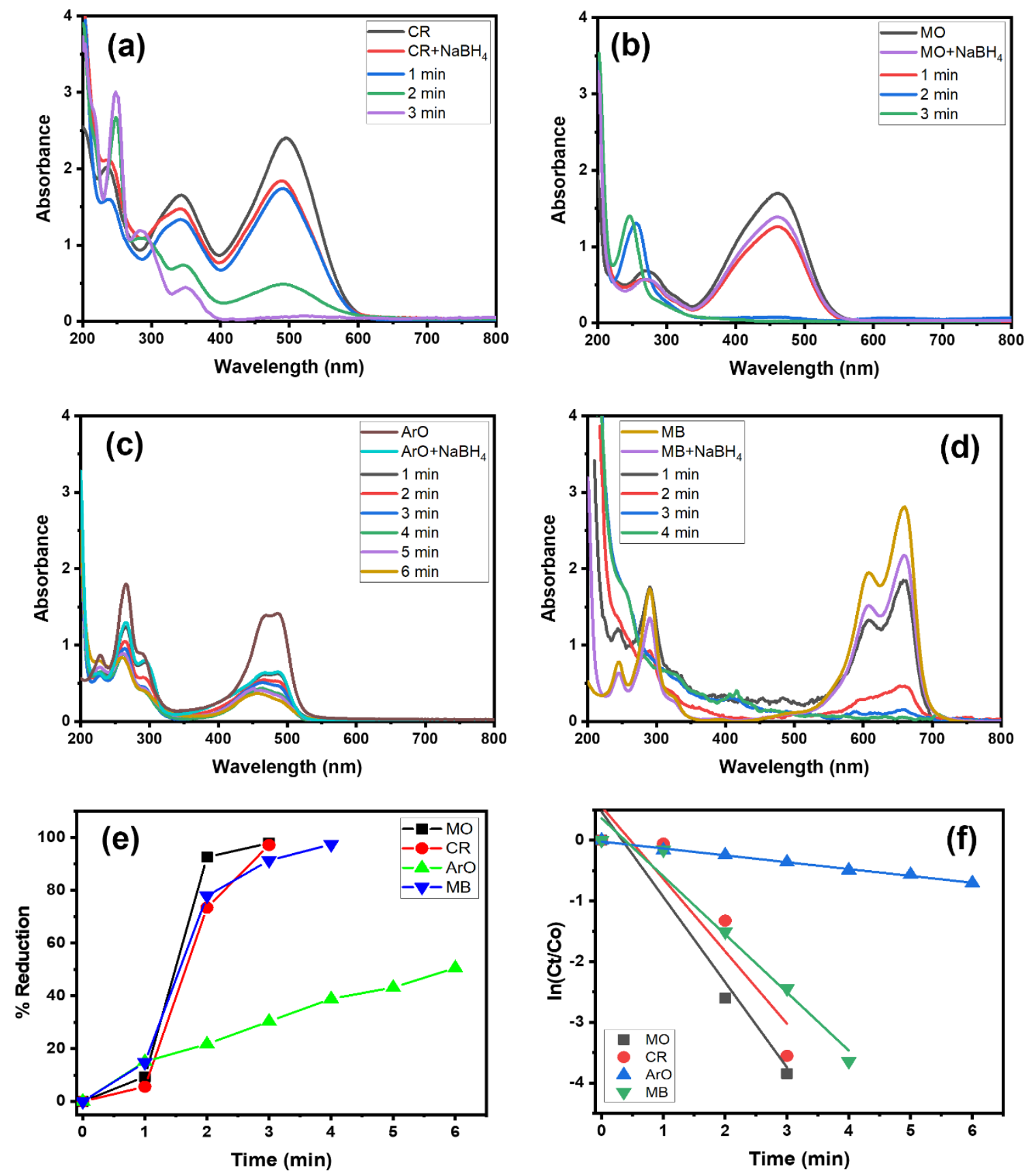

Figure 4. (a-d) UV-Vis spectra, (e) \% reduction and (f) kinetics of $\mathrm{CR}, \mathrm{MO}, \mathrm{ArO}$ and $\mathrm{MB}$ reduction by $\mathrm{NaBH}_{4}$ using 10 mg Alg@ $\mathrm{Cu}_{2} \mathrm{O}-\mathrm{Sb}_{2} \mathrm{O}_{3}$ nanocatalyst.

\subsubsection{Reduction of Nitrophenols}

$\mathrm{Alg} @ \mathrm{Cu}_{2} \mathrm{O}-\mathrm{Sb}_{2} \mathrm{O}_{3}$ was also tested in the reduction reaction of 4-NP, 2-NP and 2,6-DNP with $\mathrm{NaBH}_{4}$. Figure 6 a reveals that 4-NP displayed an absorption peak at $317 \mathrm{~nm}$. The addition of $\mathrm{NaBH}_{4}$ caused a shift in absorption from 317 to $400 \mathrm{~nm}$, signifying the formation of 4-nitrophenolate ions [24,34]. After adding Alg@ $\mathrm{Cu}_{2} \mathrm{O}-\mathrm{Sb}_{2} \mathrm{O}_{3}$, the 4-nitrophenolate band at $400 \mathrm{~nm}$ gradually declined with time, which indicated that the $-\mathrm{NO}_{2}$ group present in 4-NP got reduced to the $-\mathrm{NH}_{2}$ group. The decline in the 4-nitrophenolate ion peak was faster for Alg@C $\mathrm{u}_{2} \mathrm{O}-\mathrm{Sb}_{2} \mathrm{O}_{3}$, and the reaction was completed within 3.0 min. Similarly, $\mathrm{Alg} @ \mathrm{Cu}_{2} \mathrm{O}-\mathrm{Sb}_{2} \mathrm{O}_{3}$ was further analyzed in the reduction reaction of 2-NP and 2,6-DNP with $\mathrm{NaBH}_{4}$ using UV-Vis spectrometry. Figure 6b,c illustrates that 2-NP and 2,6-DNP gave absorption peaks at $347 \mathrm{~nm}$ and $428 \mathrm{~nm}$. Upon adding $\mathrm{NaBH}_{4}$ solution, a change of color was noticed along with a shift in the absorption band from $347 \mathrm{~nm}$ to $413 \mathrm{~nm}$ for 2-NP, signifying 
the existence of nitrophenolate ions [24,34]. Furthermore, upon adding $\mathrm{Alg} @ \mathrm{Cu}_{2} \mathrm{O}_{-} \mathrm{Sb}_{2} \mathrm{O}_{3}$, the absorption peaks recorded at $413 \mathrm{~nm}$ and $428 \mathrm{~nm}$ declined, while, on the other hand, another absorption peak at $280 \mathrm{~nm}$ could be seen with an increasing trend in intensity. The results verify the conversion of nitrophenols to aminophenol by reducing $\mathrm{NO}_{2}$ present in 2-NP and 2,6-DNP (Figure $6 \mathrm{~b}, \mathrm{c}$ ). The 2-NP and 2,6-DNP reduction reactions were faster in the presence of $\mathrm{Alg} @ \mathrm{Cu}_{2} \mathrm{O}-\mathrm{Sb}_{2} \mathrm{O}_{3}$, and both reactions were completed within $1.0 \mathrm{~min}$ and $3.0 \mathrm{~min}$, respectively. Alg@ $\mathrm{Cu}_{2} \mathrm{O}-\mathrm{Sb}_{2} \mathrm{O}_{3}$ reduced more than $97 \%$ of 4-NP, 2-NP and 2,6-DNP in $3.0 \mathrm{~min}, 1.0 \mathrm{~min}$ and $3.0 \mathrm{~min}$, respectively. Further, rate constants were obtained by applying Equation (2), and they were $1.3279 \mathrm{~min}^{-1}, 3.8187 \mathrm{~min}^{-1}$ and $1.2426 \mathrm{~min}^{-1}$ for 4-NP, 2-NP and 2,6-DNP, respectively. These results verify that the $\mathrm{Alg} @ \mathrm{Cu}_{2} \mathrm{O}-\mathrm{Sb}_{2} \mathrm{O}_{3}$ nanocatalyst is an effective catalyst, displaying more selectivity toward 2-NP.
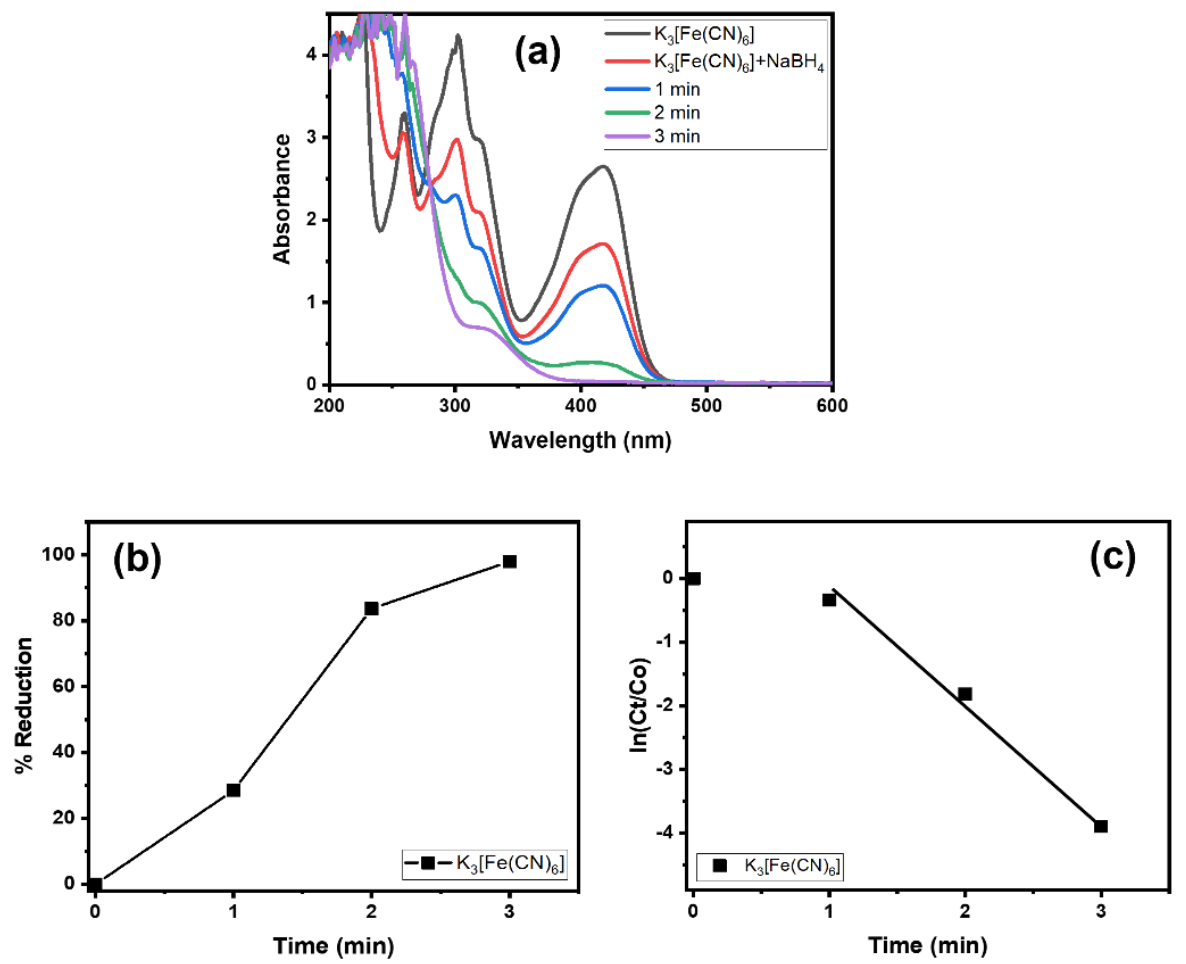

Figure 5. (a) UV-vis spectra, (b) \% reduction and (c) kinetics of $\mathrm{K}_{3}\left[\mathrm{Fe}(\mathrm{CN})_{6}\right]$ in the presence of $\mathrm{NaBH}_{4}$ using 10 mg Alg@ $\mathrm{Cu}_{2} \mathrm{O}-\mathrm{Sb}_{2} \mathrm{O}_{3}$ nanocatalyst.

\section{Effect of Catalyst Amount}

For a comprehensive study, we examined the impact of $\mathrm{Alg} @ \mathrm{Cu}_{2} \mathrm{O}-\mathrm{Sb}_{2} \mathrm{O}_{3}$ hydrogel and powder $\mathrm{Cu}_{2} \mathrm{O}_{-} \mathrm{Sb}_{2} \mathrm{O}_{3}$ amounts on 2-NP reduction using $\mathrm{NaBH}_{4}$ reducing agent. Hence, 3,5 and $10 \mathrm{mg}$ each of $\mathrm{Cu}_{2} \mathrm{O}-\mathrm{Sb}_{2} \mathrm{O}_{3}$ and $\mathrm{Alg} @ \mathrm{Cu}_{2} \mathrm{O}-\mathrm{Sb}_{2} \mathrm{O}_{3}$ nanocatalysts were added for the reduction of 2-NP to ascertain the impact of catalyst quantity (Figure 7). Figure 7g exhibits the graph of catalyst quantity vs. \% reduction as well as the time consumed while maintaining constant amounts of $\mathrm{NaBH}_{4}$ and 2-NP. The $\mathrm{Alg} @ \mathrm{Cu}_{2} \mathrm{O}-\mathrm{Sb}_{2} \mathrm{O}_{3}$ quantity plays a major role in speeding up the reaction and lowering the reaction time. $3 \mathrm{mg}, 5 \mathrm{mg}$ and $10 \mathrm{mg}$ of $\mathrm{Alg} @ \mathrm{Cu}_{2} \mathrm{O}_{-} \mathrm{Sb}_{2} \mathrm{O}_{3}$ reduced 2-NP in $8.0 \mathrm{~min}, 4.0 \mathrm{~min}$ and $1.0 \mathrm{~min}$, respectively. Meanwhile, similar amounts of powder $\mathrm{Cu}_{2} \mathrm{O}_{-} \mathrm{Sb}_{2} \mathrm{O}_{3}$ took $2.0 \mathrm{~min}$ and $1.0 \mathrm{~min}$ to reduce 2-NP. Thus, the role of $\mathrm{Cu}_{2} \mathrm{O}-\mathrm{Sb}_{2} \mathrm{O}_{3}$ and $\mathrm{Alg} @ \mathrm{Cu}_{2} \mathrm{O}-\mathrm{Sb}_{2} \mathrm{O}_{3}$ was evidently noticed, and hence, the $\mathrm{Cu}_{2} \mathrm{O}-\mathrm{Sb}_{2} \mathrm{O}_{3}$ and $\mathrm{Alg} @ \mathrm{Cu}_{2} \mathrm{O}-\mathrm{Sb}_{2} \mathrm{O}_{3}$ quantity plays a substantial role in the rate of 2-NP reduction. Therefore, $\mathrm{Cu}_{2} \mathrm{O}-\mathrm{Sb}_{2} \mathrm{O}_{3}$ is very effective, but powder $\mathrm{Cu}_{2} \mathrm{O}-\mathrm{Sb}_{2} \mathrm{O}_{3}$ has limitations, i.e., it is difficult to separate from the reaction in comparison with the present hydrogel. The powder catalyst has the drawback that it cannot be collected and separated from reaction media in order to recycle it. Hence, a requirement for a good catalyst would 
be to remove or reduce these concerns. Consequently, $\mathrm{Cu}_{2} \mathrm{O}-\mathrm{Sb}_{2} \mathrm{O}_{3}$ was packed in hydrogel for the purpose of handling and surmounting all the above-mentioned concerns.
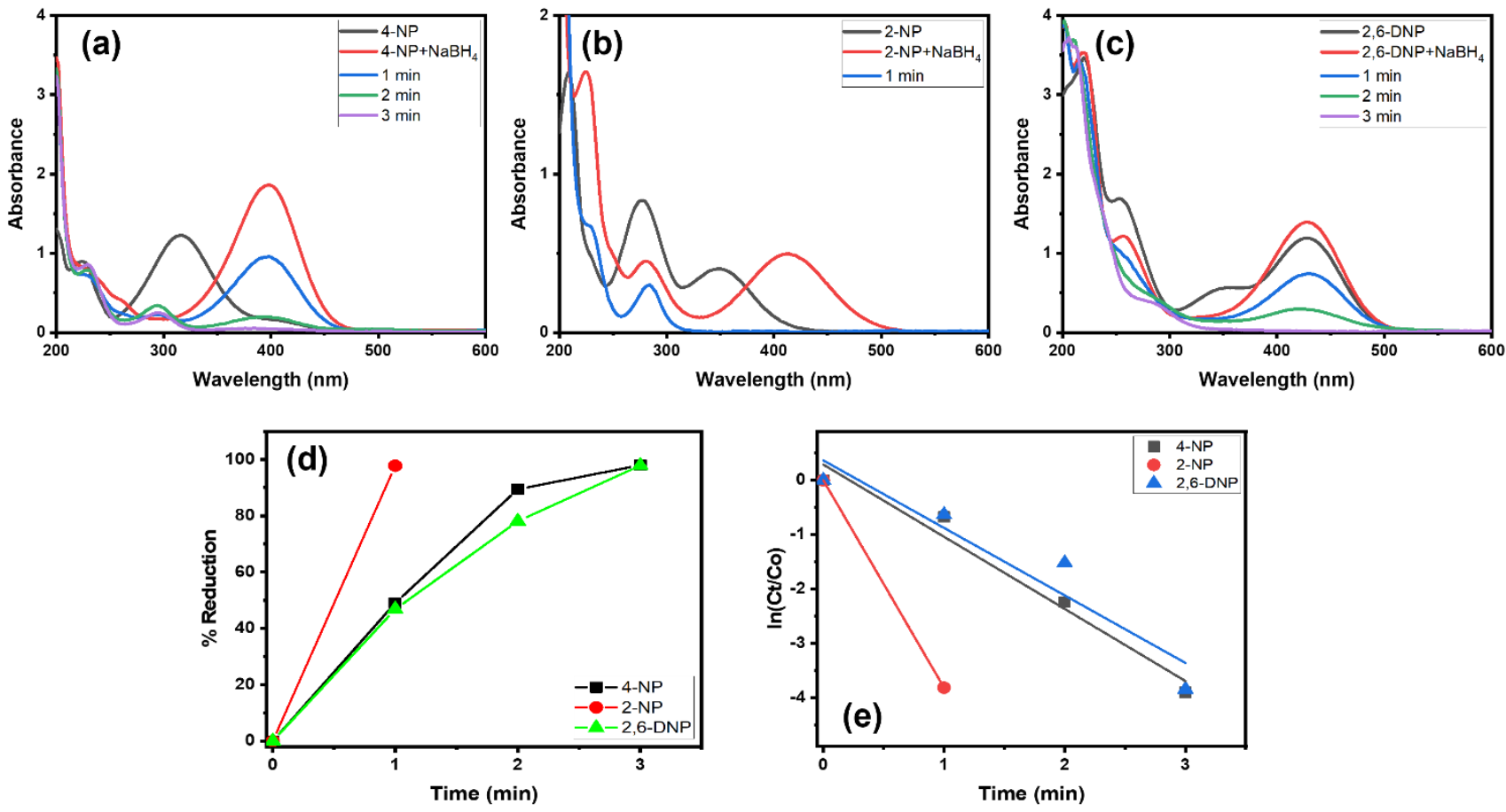

Figure 6. (a-c) UV-Vis spectra, (d) \% reduction and (e) kinetics of 4-NP, 2-NP and 2,6-DNP in the presence of $\mathrm{NaBH}_{4}$ using $10 \mathrm{mg} \mathrm{Alg} @ \mathrm{Cu}_{2} \mathrm{O}-\mathrm{Sb}_{2} \mathrm{O}_{3}$ nanocatalyst.

Effect of $\mathrm{NaBH}_{4}$ Concentration

The impact of the $\mathrm{NaBH}_{4}$ amount was assessed in the 2-NP reduction using the $\mathrm{Alg} @ \mathrm{Cu}_{2} \mathrm{O}-\mathrm{Sb}_{2} \mathrm{O}_{3}$ nanocatalyst. To scrutinize various quantities of $\mathrm{NaBH}_{4}, 0.3,0.5$ and $0.7 \mathrm{~mL}$ of $0.1 \mathrm{M} \mathrm{NaBH}_{4}$ were utilized with $5 \mathrm{mg}$ of $\mathrm{Alg} @ \mathrm{Cu}_{2} \mathrm{O}_{-} \mathrm{Sb}_{2} \mathrm{O}_{3}$. Figure 8d shows the $\%$ reduction against the time plot. 2-NP got reduced up to $95.40 \%, 96.36 \%$ and $96.43 \%$ using $0.3,0.5$ and $0.7 \mathrm{~mL}$ of $0.1 \mathrm{M} \mathrm{NaBH}_{4}$ solution. Further, the reaction rates calculated in the current study were $0.4649 \mathrm{~min}^{-1}, 0.7937 \mathrm{~min}^{-1}$ and $1.0599 \mathrm{~min}^{-1}$.

\section{Effect of 2-NP Concentration}

Moreover, we examined the catalytic behavior of $\mathrm{Alg} @ \mathrm{Cu}_{2} \mathrm{O}-\mathrm{Sb}_{2} \mathrm{O}_{3}$ in the reduction of different concentrations of 2-NP in the presence of $\mathrm{NaBH}_{4}$ (Figure 9). Consequently, various amounts of 2-NP solution $(0.056,0.074$ and $0.093 \mathrm{mM})$ were used to ascertain the catalytic ability of $\mathrm{Alg} @ \mathrm{Cu}_{2} \mathrm{O}-\mathrm{Sb}_{2} \mathrm{O}_{3}$. Alg@ $\mathrm{Cu}_{2} \mathrm{O}-\mathrm{Sb}_{2} \mathrm{O}_{3}$ reduced $92.49 \%, 97.49 \%$ and $97.36 \%$ of $0.056,0.074$ and $0.093 \mathrm{mM} \mathrm{2-NP}$ in $2.0,3.0$ and $4.0 \mathrm{~min}$ with reaction rates of $1.2946 \mathrm{~min}^{-1}, 1.1388 \mathrm{~min}^{-1}$ and $0.7939 \mathrm{~min}^{-1}$. Thus, a lower concentration of 2-NP reduces more efficiently when compared to high-concentrated 2-NP. 

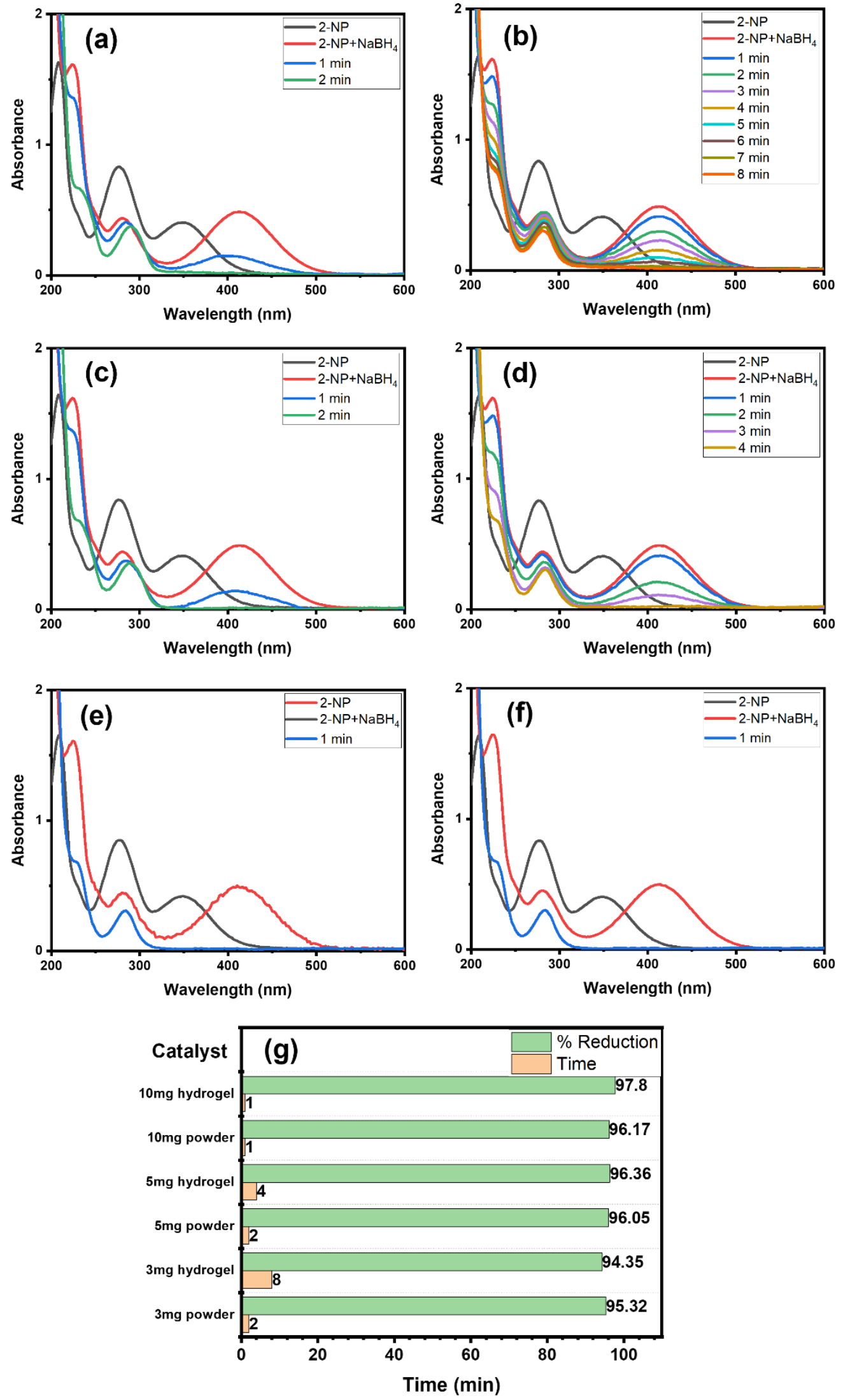

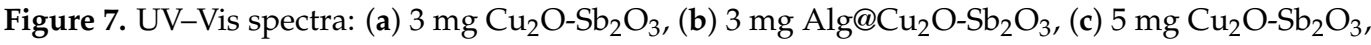

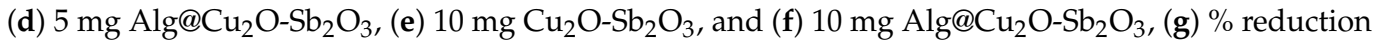
with the required time for 2-NP reduction in the presence of $\mathrm{NaBH}_{4}$. 

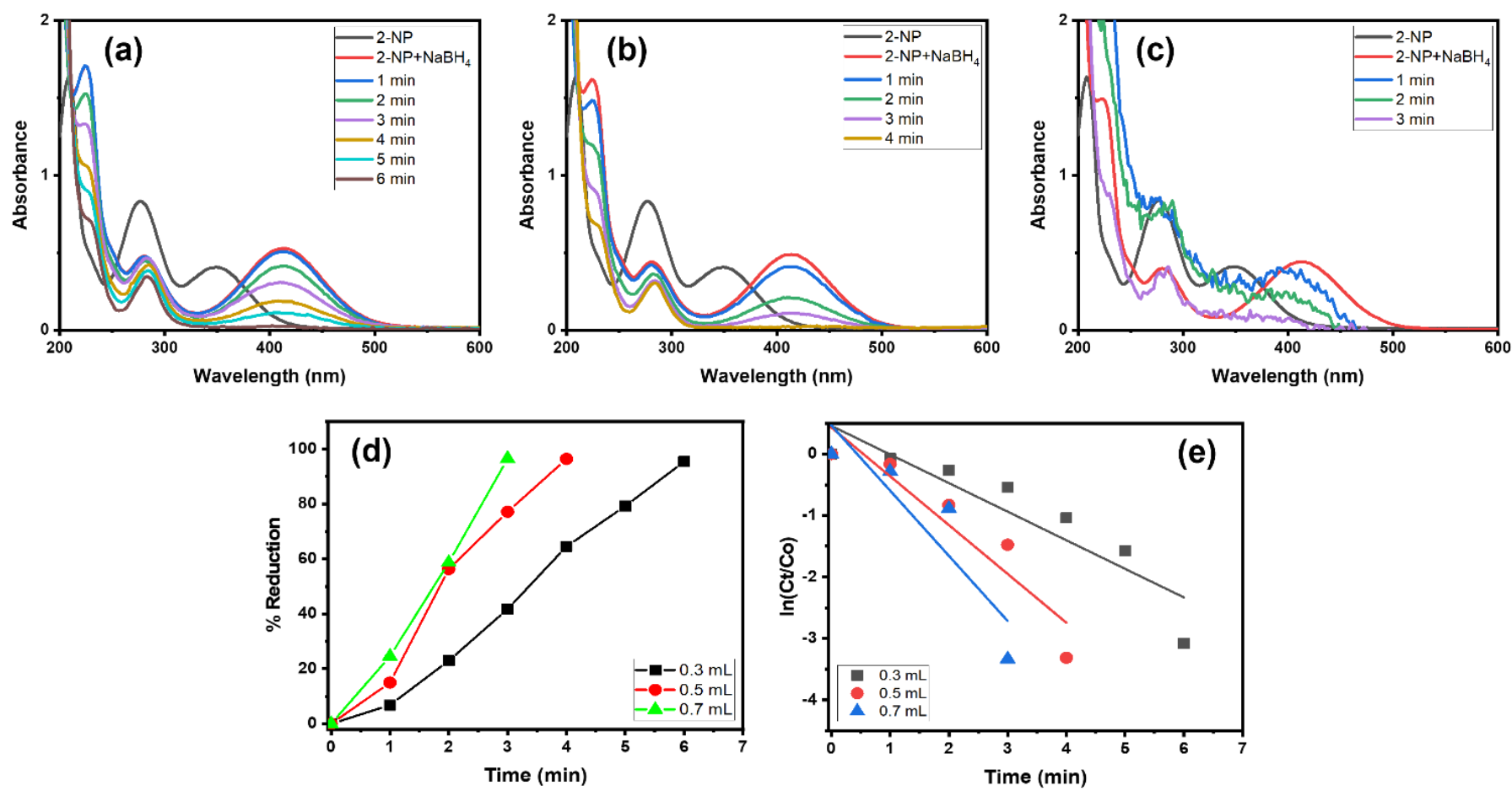

Figure 8. UV-Vis spectra in the presence of (a) $0.3 \mathrm{~mL}$, (b) $0.5 \mathrm{~mL}$ and (c) $0.7 \mathrm{~mL} \mathrm{NaBH}_{4}$, (d) \% reduction and (e) kinetics of 2-NP using 5 mg Alg@ $\mathrm{Cu}_{2} \mathrm{O}-\mathrm{Sb}_{2} \mathrm{O}_{3}$ nanocatalyst.
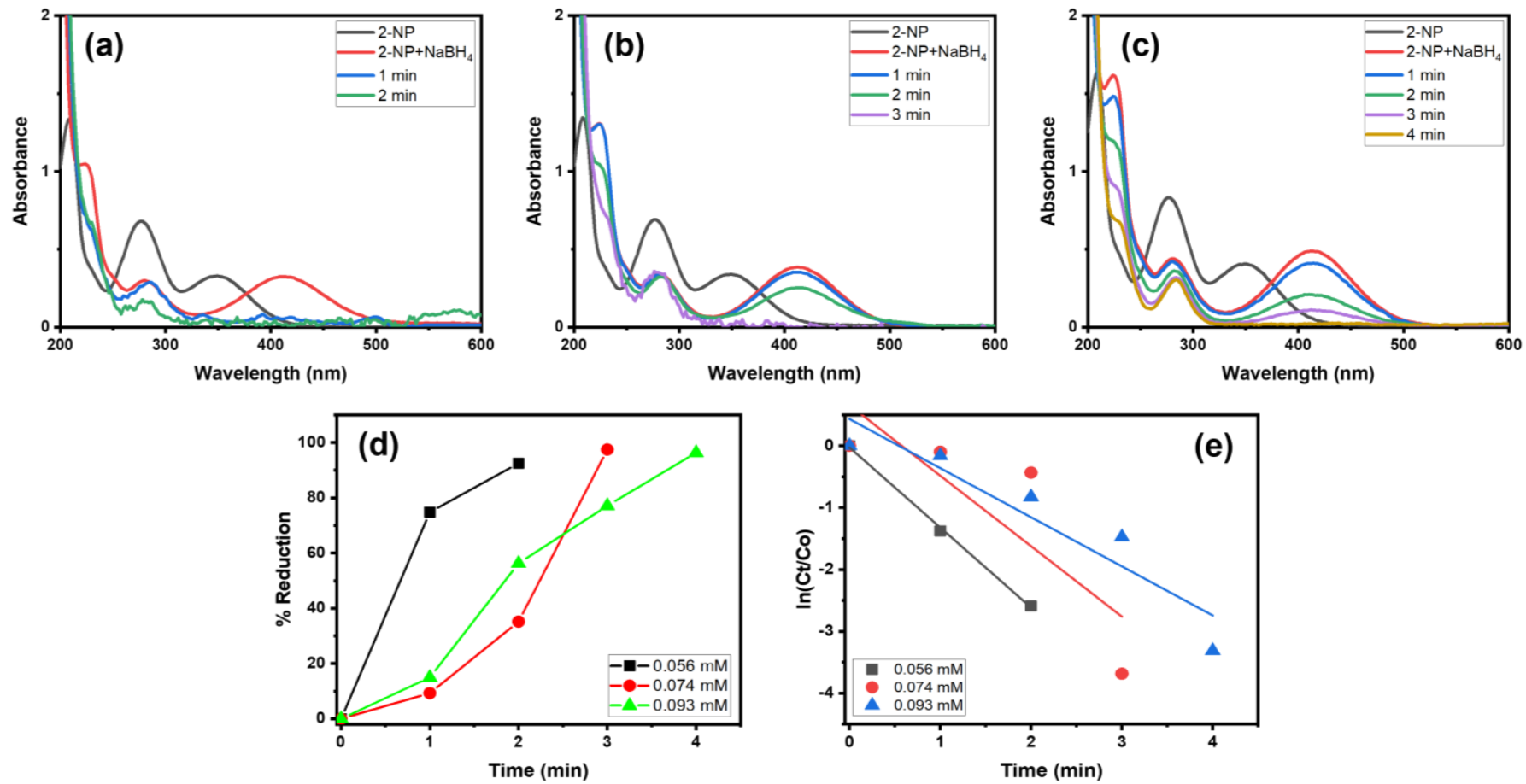

Figure 9. UV-Vis spectra of 2-NP reduction: (a) $0.065 \mathrm{mM}$, (b) $0.074 \mathrm{mM}$, and (c) $0.093 \mathrm{mM}$, (d) \% reduction and (e) kinetics using $5 \mathrm{mg} \mathrm{Alg} @ \mathrm{Cu}_{2} \mathrm{O}-\mathrm{Sb}_{2} \mathrm{O}_{3}$ and $0.5 \mathrm{~mL} \mathrm{NaBH}$.

Recyclability of Alg@ $\mathrm{Cu}_{2} \mathrm{O}-\mathrm{Sb}_{2} \mathrm{O}_{3}$

Catalyst consistency and recovery are important from an environmental and cost-based point of view [13,35]. Therefore, we checked the recyclability property of the $\mathrm{Alg} @ \mathrm{Cu}_{2} \mathrm{O}$ $\mathrm{Sb}_{2} \mathrm{O}_{3}$ nanocatalyst (Figure 10). We have analyzed the $\mathrm{Alg} @ \mathrm{Cu}_{2} \mathrm{O}_{-} \mathrm{Sb}_{2} \mathrm{O}_{3}$ nanocatalyst four times for an easy removal of the product by means of just removing the hydrogel. Figure $10 \mathrm{~d}$ specifies the time utilized for the reduction reaction of 2-NP in every cycle 
with the same Alg@ $\mathrm{Cu}_{2} \mathrm{O}-\mathrm{Sb}_{2} \mathrm{O}_{3}$ nanocatalyst, which suggests the stability as well as the recyclability property of $\mathrm{Alg} @ \mathrm{Cu}_{2} \mathrm{O}-\mathrm{Sb}_{2} \mathrm{O}_{3}$. $\mathrm{Alg} @ \mathrm{Cu}_{2} \mathrm{O}-\mathrm{Sb}_{2} \mathrm{O}_{3}$ efficiently reduced 2-NP in 4.0 min until the $3^{\text {rd }}$ cycle, which suggests that $\mathrm{Alg} @ \mathrm{Cu}_{2} \mathrm{O}-\mathrm{Sb}_{2} \mathrm{O}_{3}$ can be used numerous times with no loss in catalytic activity. The results were compared with the literature [36-40], and it was fount that $\mathrm{Alg} @ \mathrm{Cu}_{2} \mathrm{O}-\mathrm{Sb}_{2} \mathrm{O}_{3}$ is an efficient catalyst that can be used several times. This indicate that nanocomposite can play important role as a catalyst since nanocomposites have shown an enormous range of applications in different sectors [41-43].
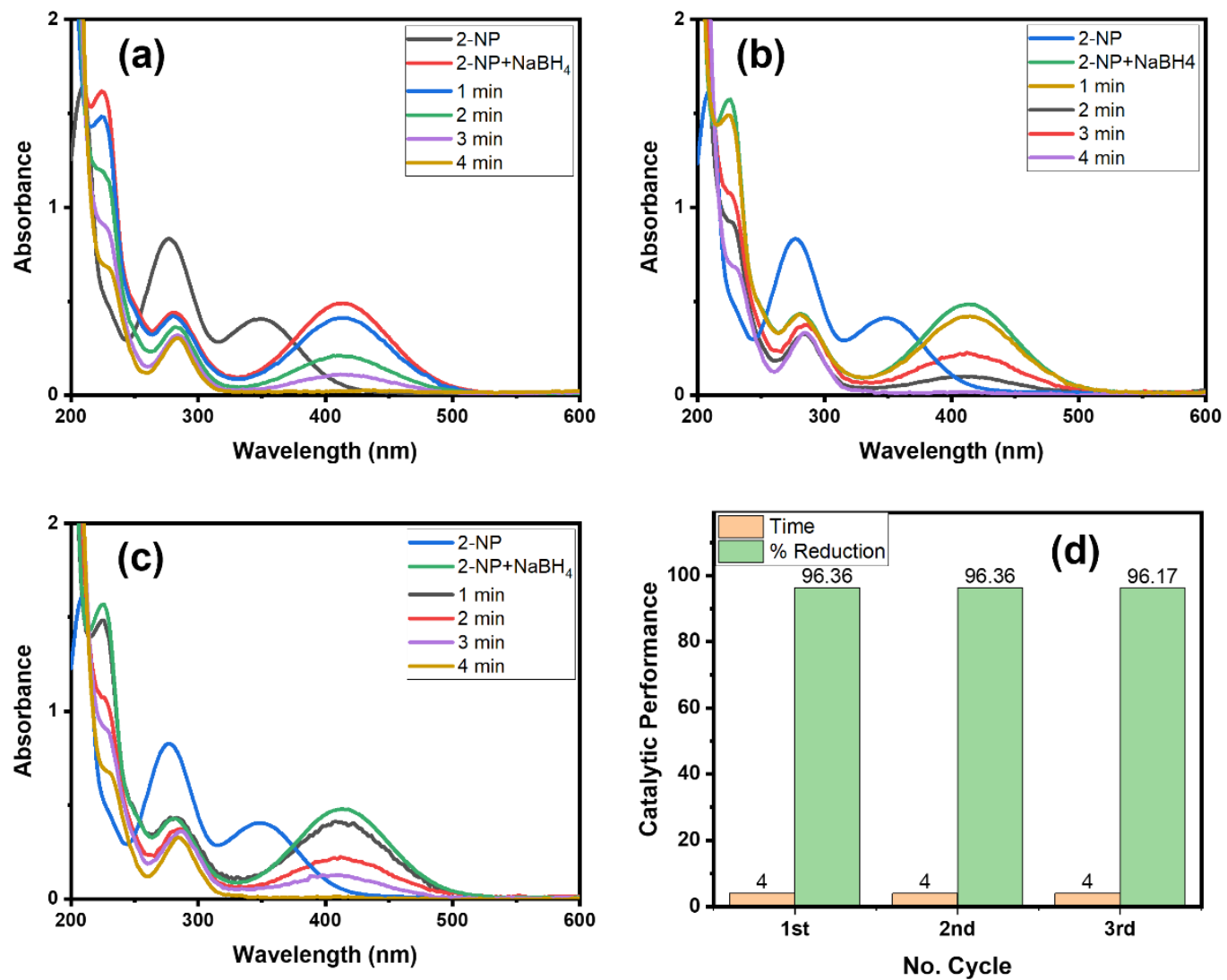

Figure 10. UV-Vis spectra for the reduction of 2-NP: (a) 1st cycle, (b) 2nd cycle, (c) 3rd cycle, and (d) comparative reduction time and \% reduction in terms of recyclability using $5 \mathrm{mg} \mathrm{Alg} @ \mathrm{Cu}_{2} \mathrm{O}_{-} \mathrm{Sb}_{2} \mathrm{O}_{3}$ in $2 \mathrm{~mL} \mathrm{2-NP}$ and $0.5 \mathrm{~mL} \mathrm{NaBH}_{4}$.

\section{Conclusions}

$\mathrm{Cu}_{2} \mathrm{O}-\mathrm{Sb}_{2} \mathrm{O}_{3}$ nanoparticles were prepared and placed inside the Alg hydrogel. Both $\mathrm{Cu}_{2} \mathrm{O}-\mathrm{Sb}_{2} \mathrm{O}_{3}$ and $\mathrm{Alg} @ \mathrm{Cu}_{2} \mathrm{O}-\mathrm{Sb}_{2} \mathrm{O}_{3}$ nanocatalysts were excellent catalysts for the selective reduction reaction of 2-NP. The influence of various parameters on the 2-NP reduction using $\mathrm{Alg} @ \mathrm{Cu}_{2} \mathrm{O}-\mathrm{Sb}_{2} \mathrm{O}_{3}$ showed that increasing the catalyst and $\mathrm{NaBH}_{4}$ amounts and decreasing the 2-NP concentration preceded a greater catalytic efficiency. The rate constant when utilizing 10 mg Alg@ $\mathrm{Cu}_{2} \mathrm{O}-\mathrm{Sb}_{2} \mathrm{O}_{3}$ was calculated as being $3.8187 \mathrm{~min}^{-1}$ for the 2-NP reduction. Lastly, Alg@ $\mathrm{Cu}_{2} \mathrm{O}-\mathrm{Sb}_{2} \mathrm{O}_{3}$ maintained a greater activity after recyclability assessments.

Author Contributions: Conceptualization, S.B.K. and Y.S.; methodology, S.B.K.; software, T.K.; validation, T.K., Y.S. and A.M.A.; formal analysis, K.A.; investigation, E.M.B.; resources, A.M.A.; data curation, E.M.B.; writing—original draft preparation, K.A.; writing—review and editing, E.M.B.; visualization, T.K.; supervision, A.M.A.; project administration, K.A.; funding acquisition, S.B.K. All authors have read and agreed to the published version of the manuscript.

Funding: This research received no external funding.

Institutional Review Board Statement: Not applicable.

Informed Consent Statement: Not applicable. 
Data Availability Statement: The data presented in this study are available on request from the corresponding author.

Acknowledgments: The authors extend their appreciation to the Deputyship for Research \& Innovation, Ministry of Education in Saudi Arabia for funding this research work through the project number (IFPNC-007-130-2020) and King Abdulaziz University, DSR, Jeddah, Saudi Arabia.

Conflicts of Interest: The authors declare no conflict of interest.

\section{References}

1. Dudgeon, D.; Arthington, A.H.; Gessner, M.O.; Kawabata, Z.-I.; Knowler, D.J.; Lévêque, C.; Naiman, R.J.; Prieur-Richard, A.-H.; Soto, D.; Stiassny, M.L.J.; et al. Freshwater biodiversity: Importance, threats, status and conservation challenges. Biol. Rev. 2006, 81, 163-182. [CrossRef] [PubMed]

2. Horton, A.A.; Walton, A.; Spurgeon, D.J.; Lahive, E.; Svendsen, C. Microplastics in freshwater and terrestrial environments: Evaluating the current understanding to identify the knowledge gaps and future research priorities. Sci. Total Environ. 2017, 586, 127-141. [CrossRef]

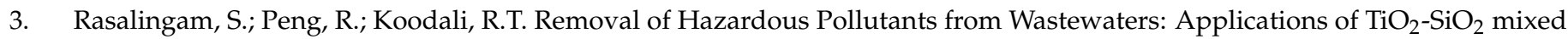
oxide materials. J. Nanomater. 2014, 2014, 617405. [CrossRef]

4. Khan, S.A.; Bakhsh, E.M.; Asiri, A.M.; Khan, S.B. Chitosan coated NiAl layered double hydroxide microsphere templated zero-valent metal NPs for environmental remediation. J. Clean. Prod. 2021, 285, 124830. [CrossRef]

5. Villegas, L.G.C.; Mashhadi, N.; Chen, M.; Mukherjee, D.; Taylor, K.E.; Biswas, N. A short review of techniques for phenol removal from wastewater. Curr. Pollut. Rep. 2016, 2, 157-167. [CrossRef]

6. Maslamani, N.; Khan, S.B.; Danish, E.Y.; Bakhsh, E.M.; Zakeeruddin, S.M.; Asiri, A.M. Super adsorption performance of carboxymethyl cellulose/copper oxide-nickel oxide nanocomposite toward the removal of organic and inorganic pollutants. Environ. Sci. Pollut. Res. 2021, 28, 38476-38496. [CrossRef]

7. Tanikkul, S.; Jakmunee, J.; Lapanantnoppakhun, S.; Rayanakorn, M.; Sooksamiti, P.; Synovec, R.E.; Christian, G.D.; Grudpan, K. Flow injection invalve mini-column pretreatment combined with ion chromatography for cadmium, lead and zinc determination. Talanta 2004, 64, 1241-1246. [CrossRef] [PubMed]

8. Raza, W.; Lee, J.; Raza, N.; Luo, Y.; Kim, K.-H.; Yang, J. Removal of phenolic compounds from industrial waste water based on membrane-based technologies. J. Ind. Eng. Chem. 2019, 71, 118. [CrossRef]

9. Zhu, J.; Zhang, X.; Qin, Z.; Zhang, L.; Ye, Y.; Cao, M.; Gao, L.; Jiao, T. Preparation of PdNPs doped chitosan-based composite hydrogels as highly efficient catalysts for reduction of 4-nitrophenol. Colloids Surf. A Physicochem. Eng. Asp. 2021, 611, 125889. [CrossRef]

10. Xie, R.; Wei, T.; Bai, S.; Wang, Z.; Chai, F.; Chen, L.; Zang, S. The synthesis and catalytic activity of bimetallic CuAg nanoparticles and their magnetic hybrid composite materials. New J. Chem. 2020, 44, 9684-9690. [CrossRef]

11. Danish, E.Y.; Bakhsh, E.M.; Akhtar, K. Design of chitosan nanocomposite hydrogel for sensitive detection and removal of organic pollutants. Int. J. Biol. Macromol. 2020, 159, 276-286. [CrossRef]

12. Khan, S.B.; Ahmad, S.; Kamal, T.; Asiri, A.M.; Bakhsh, E.M. Metal nanoparticles decorated sodium alginate-carbon nitride composite beads as effective catalyst for the reduction of organic pollutants. Int. J. Biol. Macromol. 2020, 164, 1087-1098. [CrossRef]

13. Akhtar, K.; Ali, F.; Sohni, S.; Kamal, T.; Asiri, A.M.; Bakhsh, E.M.; Khan, S.B. Lignocellulosic biomass supported metal nanoparticles for the catalytic reduction of organic pollutants. Environ. Sci. Pollut. Res. 2020, 27, 823-836. [CrossRef]

14. Naseem, K.; Farooqi, Z.H.; Begum, R.; Irfan, A. Removal of Congo red dye from aqueous medium by its catalytic reduction using sodium borohydride in the presence of various inorganic nano-catalysts: A review. J. Clean. Prod. 2018, 187, 296-307. [CrossRef]

15. Bakhsh, E.M.; Khan, S.B.; Asiri, A.M.; Shah, A. Zn/Fe nanocomposite based efficient electrochemical sensor for the simultaneous detection of metal ions. Phys. E Low-Dimens. Syst. Nanostruct. 2021, 130, 114671. [CrossRef]

16. Khan, S.B.; Khan, M.S.J.; Kamal, T.; Asiri, A.M.; Bakhsh, E.M. Polymer supported metallic nanoparticles as a solid catalyst for the removal of organic pollutants. Cellulose 2020, 27, 5907-5921. [CrossRef]

17. Jang, E.S.; Khan, S.B.; Seo, J.; Nam, Y.H.; Choi, W.J.; Akhtar, K.; Han, H. Synthesis and characterization of novel UV-curable polyurethane-clay nanohybrid: Influence of organically modified layered silicates on the properties of polyurethane. Prog. Org. Coat. 2011, 71, 36-42. [CrossRef]

18. Gul, S.; Rehan, Z.A.; Khan, S.A.; Akhtar, K.; Khan, M.A.; Khan, M.I.; Rashid, M.I.; Asiri, A.M.; Khan, S.B. Antibacterial PES-CA$\mathrm{Ag}_{2} \mathrm{O}$ nanocomposite supported $\mathrm{Cu}$ nanoparticles membrane toward ultrafiltration, BSA rejection and reduction of nitrophenol. J. Mol. Liq. 2017, 230, 616-624. [CrossRef]

19. Lee, Y.; Kim, D.; Seo, J.; Han, H.; Khan, S.B. Preparation and characterization of poly(propylene carbonate)/exfoliated graphite nanocomposite films with improved thermal stability, mechanical properties and barrier properties. Polym. Int. 2013, 62, 1386-1394. [CrossRef]

20. Bakhsh, E.M.; Akhtar, K.; Fagieh, T.M.; Khan, S.B.; Asiri, A.M. Development of alginate@tin oxide-cobalt oxide nanocomposite based catalyst for the treatment of wastewater. Int. J. Biol. Macromol. 2021, 187, 386-398. [CrossRef] [PubMed]

21. Khan, S.B.; Kamal, T.; Asiri, A.M.; Bakhsh, E.M. Iron doped nanocomposites based efficient catalyst for hydrogen production and reduction of organic pollutant. Colloids Surf. A Physicochem. Eng. Asp. 2021, 608, 125502. [CrossRef] 
22. Khan, S.B.; Khan, M.S.J.; Akhtar, K.; Bakhsh, E.M.; Kamal, T.; Asiri, A.M.; Shen, Y. Design of efficient solar photocatalytic system for hydrogen production and degradation of environmental pollutant. J. Mater. Res. Technol. 2021, 14, 2497-2512. [CrossRef]

23. Danish, M.S.; Bhattacharya, A.; Stepanova, D.; Mikhaylov, A.; Grilli, M.L.; Khosravy, M.; Senjyu, T. A systematic review of metal oxide applications for energy and environmental sustainability. Metals 2020, 10, 1604. [CrossRef]

24. Khan, S.B.; Akhtar, K.; Bakhsh, E.M.; Asiri, A.M. Electrochemical detection and catalytic removal of 4-nitrophenol using $\mathrm{CeO}_{2}-\mathrm{Cu}_{2} \mathrm{O}$ and $\mathrm{CeO}_{2}-\mathrm{Cu}_{2} \mathrm{O} / \mathrm{CH}$ nanocomposites. Appl. Surf. Sci. 2019, 492, 726-735. [CrossRef]

25. Vázquez-López, A.; Yaseen, A.; Maestre, D.; Ramírez-Castellanos, J.; Marstein, E.S.; Karazhanov, S.Z.; Cremades, A. Synergetic improvement of stability and conductivity of hybrid composites formed by PEDOT:PSS and SnO nanoparticles. Molecules 2020, 25, 695. [CrossRef] [PubMed]

26. Janardhan, E.; Reddy, M.M.; Reddy, P.V.; Reddy, M.J. Synthesis of SnO nanoparticles-A hydrothermal approach. World J. Nano Sci. Eng. 2018, 8, 33-37. [CrossRef]

27. Marwani, H.M.; Bakhsh, E.M.; Khan, S.B.; Danish, E.Y.; Asiri, A.M. Cerium oxide-cadmium oxide nanomaterial as efficient extractant for yttrium ions. J. Mol. Liq. 2018, 269, 252-259. [CrossRef]

28. Chen, X.; Wang, X.; An, C.; Liu, J.; Qian, Y. Synthesis of $\mathrm{Sb}_{2} \mathrm{O}_{3}$ nanorods under hydrothermal conditions. Mater. Res. Bull. 2005, 40, 469-474. [CrossRef]

29. Liu, Y.; Wang, H.; Yang, K.; Yang, Y.; Ma, J.; Pan, K.; Wang, G.; Ren, F.; Pang, H. Enhanced electrochemical performance of $\mathrm{Sb}_{2} \mathrm{O}_{3}$ as an anode for lithium-ion batteries by a stable cross-linked binder. Appl. Sci. 2019, 9, 2677. [CrossRef]

30. Khan, S.A.; Khan, S.B.; Farooq, A.; Asiri, A.M. A facile synthesis of CuAg nanoparticles on highly porous ZnO/carbon blackcellulose acetate sheets for nitroarene and azo dyes reduction/degradation. Int. J. Biol. Macromol. 2019, 130, 288-299. [CrossRef]

31. Wang, W.; Wang, F.; Kang, Y.; Wang, A. Facile self-assembly of Au nanoparticles on a magnetic attapulgite $/ \mathrm{Fe}_{3} \mathrm{O}_{4}$ composite for fast catalytic decoloration of dye. RSC Adv. 2013, 3, 11515-11520. [CrossRef]

32. Khan, F.U.; Asimullah; Khan, S.B.; Kamal, T.; Asiri, A.M.; Khan, I.U.; Akhtar, K. Novel combination of zero-valent Cu and Ag nanoparticles @ cellulose acetate nanocomposite for the reduction of 4-nitro phenol. Int. J. Biol. Macromol. 2017, 102, 868-877. [CrossRef] [PubMed]

33. Veerakumar, P.; Salamalai, K.; Thanasekaran, P.; Lin, K.-C. Simple preparation of porous carbon-supported ruthenium: Propitious catalytic activity in the reduction of ferrocyanate(III) and a cationic dye. ACS Omega 2018, 3, 12609-12621. [CrossRef]

34. Bae, S.; Gim, S.; Kim, H.; Hanna, K. Effect of $\mathrm{NaBH}_{4}$ on properties of nanoscale zero-valent iron and its catalytic activity for reduction of p-nitrophenol. Appl. Catal. B Environ. 2016, 182, 541-549. [CrossRef]

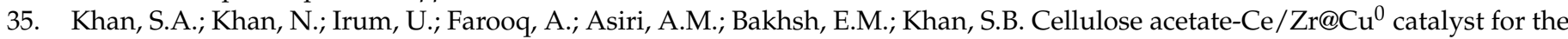
degradation of organic pollutant. Int. J. Biol. Macromol. 2020, 153, 806-816. [CrossRef] [PubMed]

36. Sahiner, N.; Ozay, H.; Ozay, O.; Aktas, N. New catalytic route: Hydrogels as templates and reactors for in situ Ni nanoparticle synthesis and usage in the reduction of 2- and 4-nitrophenols. Appl. Catal. A Gen. 2010, 385, 201-207. [CrossRef]

37. Korobeinyk, A.V.; Whitby, R.D.L.; Mikhalovsky, S.V.; Inglezakis, V.J. In situ production of high purity noble metal nanoparticles on fumed silica and catalytic activity towards 2-nitrophenol reduction. J. Phys. Chem. Solids 2019, 127, 28-34. [CrossRef]

38. Ismail, M.; Khan, M.I.; Khan, S.B.; Akhtar, K.; Khan, M.A.; Asiri, A.M. Catalytic reduction of picric acid, nitrophenols and organic azo dyes via green synthesized plant supported Ag nanoparticles. J. Mol. Liq. 2018, 268, 87-101. [CrossRef]

39. Khan, S.B. Metal nanoparticles containing chitosan wrapped cellulose nanocomposites for catalytic hydrogen production and reduction of environmental pollutants. Carbohydr. Polym. 2020, 242, 116286. [CrossRef]

40. Mahmoud, M.E.; Amira, M.F.; Abouelanwar, M.E.; Seleim, S.M. Catalytic reduction of nitrophenols by a novel assembled nanocatalyst based on zerovalent copper-nanopolyaniline-nanozirconium silicate. J. Mol. Liq. 2020, 299, 112192. [CrossRef]

41. Fagieh, T.M.; Bakhsh, E.M.; Khan, S.B.; Akhtar, K.; Asiri, A.M. Alginate/banana waste beads supported metal nanoparticles for efficient water remediation. Polymers 2021, 13, 4054. [CrossRef] [PubMed]

42. Gul, S.; Khan, S.B.; Rehman, I.U.; Khan, M.A.; Khan, M.I. A comprehensive review of magnetic nanomaterials modern day theranostics. Front. Mater. Polym. Compos. Mater. 2019, 6, 179. [CrossRef]

43. Kim, D.; Jung, J.; Kim, Y.; Lee, M.; Seo, J.; Khan, S.B. Structure and thermal properties of octadecane/expanded graphite composites as shape-stabilized phase change materials. Int. J. Heat Mass Transf. 2016, 95, 735-741. [CrossRef] 